\title{
Recount Text in SFL Perspective: Pedagogical Implication based on Student's Writing Analysis
}

\author{
Laxmi Mustika Cakrawati \\ Universitas Pendidikan Indonesia \\ laxmicakrawati@student.upi.edu \\ DOI : http://dx.doi.org/10.18326/rgt.v11i2.210-227
}

\begin{abstract}
Submission
ABSTRACT

Track:

Received:

$01 / 04 / 2018$

Recount can be considered as one of the easier type of text that can be written by students. This might be the reason why the text is learned in both junior and senior high school level. However, there are still a lot

Final Revision: $25 / 11 / 2018$ of students who cannot produce the text well. This study was aimed to analyze student's recount text based on three metafunctions in SFL perspective. It is expected that by identifying students' problems,

Available online: $01 / 12 / 2018$ teachers can decide and design appropriate pedagogical plan. The result of the study reveals that the student's major problems in producing recount text are the use of subject and verb tense (interpersonal metafunctions), the generic structure of the text, the use of conjunctions, the grammatical errors, and L1 interference. Therefore, considering the problems found in the student's recount text, POWER strategy is proposed as one of strategies can be applied by teachers in teaching writing, particularly teaching recount text.

Keywords: recount text, systemic functionl linguistics, metafunction, POWER strategy
\end{abstract}

\section{INTRODUCTION}

The term genre has been widely used in media and literary world. In linguistics and language learning, the term has also been used recently. In systemic functional linguistics, genre is seen as staged, goal oriented social process achieved primarily through language. It is suggested that curriculum activities should engage students in using language for social purposes as explaining, describing, arguing, reviewing, recounting, and storytelling. Therefore, the content of curriculum should be made explicit both in terms of topics and in terms of genres involved in the topics (Derewianka, 2015).

Since genre-based approach has contributed significant development in solving literacy problem in Australia, the approach is becoming increasingly prominent in the field of English language teaching (Derewianka, 2013). Thus, many countries as well as Indonesia implement 
the approach. Systemic functional linguistic genre pedagogy (SFL GP) has existed in Indonesia since 2004. The approach was adapted to curriculum for teaching English in Indonesian school to improve students' ability in English.

By implementing genre-based approach, it is hoped that teachers will be able to guide students to understand the text not only as a group of sentences but also as a tool for achieving purposes in communication.

Hyland (2004) in Lee (2012) defined genre as a term used for identifying different types of text. Martin (1990) and Swales (1990) stated that genre is a goal oriented activity in communication. The members involve in the process of communication will set goals regarding to certain event and social context. Thus, it can be said that genre is either oral or written text which portrays the relationship between language and its social function. (Dirgeyasa, 2016). It is also in line with Martin (1993) who defined genre as "a staged, goaloriented social processes which integrate field (the subject-matter of the text), mode (the channel of communication being used - whether it is written or spoken), and tenor (participants) choices in predictable ways. It means that the concept of genre intertwine with the way in achieving social purposes. Derewianka (1990) identified six main genres based on their purposes: (a) narratives: usually to entertain, (b) recount: to tell what happened, (c) information reports: to provide factual information, (d) instruction: to tell the listeners or readers what to do, (e) explanation: to explain why or how something happens, and (f) expository: to present or argue a viewpoint. These social purposes will determine the schematic structure or organization of the text and particular language features that the writers have to use.

Related to genre in language learning, educators has been already familiar with the term genre pedagogies or genre based approaches. Hyon (1996) in Najmi (2015) stated that a genre-based approach focuses on the relationship between text-genres and their contexts. Genre-based approach highlights writing as a social activity. It stresses on the linguistic conventions, the role of writer-reader interaction, and the importance of exploring the social and cultural context of language use on a piece of writing in order to be successfully accepted by readers. A genre-based approach can help students not only to identify purpose, audience, and context of writing but also to help them understand the ways structural and language features of written text can influence meaning making. Likewise, Tardy (2011) stated that in second language contexts, genre pedagogies can be beneficial to help teachers in providing targeted instruction to meet students' needs related to language and writing (Lee, 2012). Genre pedagogies also promise very real benefits for learners as it stresses that genres are 
specific to particular cultures. It can also help students to exploit the expressive potential of society's discourse structures instead of merely being manipulated by them (Hyland, 2007).

Genre-based approaches focus on written discourse as a mean to construct meaning for the right audience and appropriate context. In genre-based approaches, the emphasis is the creation of meaning at the level of the whole text. Genre theory starts from the premise that language use is goal-oriented and evolve within a culture to enable members of that culture achieve their social purposes. Since genre approach involves metalinguistic terms, vocabulary, and text structure, it cannot be easily implemented in the classroom. Thus, in this approach, teachers have an important role to provide instructional scaffolding.

In teaching and learning process, implementing genre-based approach means teaching students to use particular language patterns to accomplish coherent writing and how to achieve their purpose through writing. Thus, teachers should be able to provide systematic guidance and engage students in meaningful activities so that they can understand the pattern of each genre and finally be able to produce their own text.

Genre theory provides all students to have access to the powerful discourse of the culture. It regards language as the primary resource for meaning-making and foundation of learning. The theory also helps students to interpret the relationship between language and context. At the more specific level, genre theory enables students to understand how register of a particular situation is related to certain language choice, how the various fields of knowledge utilize different language resources, how the tenor of the classroom varies as the participants involve in different relationship, and how oral and written modes play different roles in learning process.

\section{Recount Text}

Recount is one of texts that learned both in junior high school level and senior high school level. In schools, students usually learn recount text in form of personal recount and biography. According to Derewianka (1990), recount is a development of a sequence of events and in recount, writers reconstruct past experience. Meanwhile, based on Knapp's genre model (Knapp \& Watkins, 2005), we can say that personal and historical recount are products of the process of narrate through the process of sequencing people and events in time and space. 


\section{Common Features of Recount Text}

According to Derewianka (1990) and Gerot \& Wignel (1995), the purpose of recount text is to tell what happened or to retell events for the purpose of informing and entertaining. Similarly, Butt, et al (2006) mentioned that the function of recount text is to tell what happened and to document sequence of events and evaluate their significance in some way.

Derewianka (1990) divided recount text into three types: personal recount, factual recount, and imaginative recount. The specific purpose of the first type is to retell an activity that the writer/ speaker have been personally involved in (e.g. oral anecdote, diary entry). While factual recount is aimed to record the particulars of an incident (e.g. report of a science experiment, police report, news report, historical account), the imaginative recount is aimed to talk on an imaginary role and giving details of events (e.g. a day in the life of a Roman slaver, how I invented...).

Since each type has its own specific purpose, there are slight differences in each language features of the text. Generally, recount will focus on specific participants, the use of temporal sequence, the use of simple past tense, the use of action verbs (material process), and the existence of linking words to do with time (circumstances of time) and place. Normally, details irrelevant to the purpose of the text should be avoided. In addition, specifically, personal recount use the first person pronoun. Personal responses to the events and details are often added to add interest or humor. In factual recount, readers can see the use of third person pronouns and passive voice. Details of time, place, manner, and descriptive details may be required to provide precise information and to help reader reconstruct the activity or incident accurately. Sometimes, the ending of the text describes the outcome of the activity and the personal feeling is probably not appropriate to be included in the text. In imaginative recount, the first person pronoun is used but it may be appropriate to include writers' personal reactions.

Although there are few differences in language features of recount text, each type of recount text consists of the same structure.

- Orientation: provides the reader/ listener the background information needed to understand the text (who was involved, where it happened, when it happened)

- Series of events: tell what happened, ordered in a chronological sequence.

- Re-orientation: optional - closure of events. At various stages, there may be some personal comment on an incident 


\section{Recount Text in Metafunction Perspective}

The theory of SFL emphasizes that language has three general functions: the interpersonal metafunction, the ideational or experiential metafunction, and the textual metafunction. These three metafunction perspective will influence texts to achieve their social purposes.

\section{a. Interpersonal Metafunction}

Interpersonal metafunction deals with the relationship that is portrayed in the text. The overall structure will be varied due to the purpose of each text and the language features of the text will be different because the register of the text are different. It means that the situation in which the text is produced differed in terms of tenor, field, and mode (Derewianka, 1990). The tenor of a text will depend on the relationship and the roles of the participants involved in the text. In written discourse such as recount text, if the writer and reader are not personally known each other, we can see the neutral tenor which describes formality and no expression of personal feelings and emotion. On the other hand, when students construct a text about their holiday experience in which their friends are the target readers, the use of personal pronoun, expression of personal feelings and emotion can be seen in the text. The field of the text deals with a situation refers to what's going on and the circumstances in which they are taking place and the mode of the text refers to the channel of communication used through the participants. It covers how distant the speaker - listener or the writer - reader is and the extent to which the language accompanies the action going on.

Interpersonal metafunction also deals with the purposes of communicative exchange that are giving - demanding information and demanding goods and service. Since recount text belongs to written discourse, the sentences used in recount texts are usually in the form of declarative sentences. The sentence of recount text can also be analyzed using two main grammatical features related to interpersonal meanings: the Subject and the Finite which are combined to make the Mood of a clause.

\section{b. Ideational/ Experiential Metafunction}

Ideational or experiential metafunction deals with the experiences which are explained by language. It is also known as the field of experience (Emilia, 2005). By analyzing clause or text using the experiential metafunction, readers can know the overall meaning 
or content meanings of a clause or text regarding what/ who did what to what/ whom. The experiential perspective focuses on the action expressed in the main verb of a clause. One of basic ways in analyzing experiential metafunction is transitivity that is used to refer a system for describing the whole clause. Processes are central point in transitivity. There are four main categories of processes: material, mental, relational, and verbal. Two additional categories of process are called as behavioral and existential processes.

Although other processes can be found in recount text, it has been mentioned that generally, recount employs material processes. Material process shows that something physically doing something which may be done to some other thing (Thompson, 2014). The 'doer' of the action is called the Actor and when the action is being done to another participant, the second participant is called as the Goal.

\section{c. Textual Metafunction}

The textual metafunction deals with the role that language plays in context and how language works to create connected and coherent discourse. There are three main ways in which textual meanings are constructed in a text: repetition, conjunction, and thematization (Thompson, 2014). Repetition in a text includes repetition of the same word or a synonym. The repetition is used to indicate the speaker's or writer's focus on certain topic. In the text sample above, it can be seen that the writer of the text repeat the words Warilla and Gerringong few times to maintain the focus of the readers since the text tells them about the grand final match between Warilla and Gerringong. The second way is conjunction. Conjunction is used to combine two or more clauses to show that the parts of a text are related in some way. The last way is thematization which relates to the structuring of a clause or the order in which elements appear in the clause. Since the beginning of a clause is a prominent part, the theme of a clause is the first element appears in a clause while the rest of the clause can be called as the Rheme. According to Halliday and Matthiessen (2014) in Thompson (2014), Theme is the point of departure of the message. The Theme has main function to indicate the progression of 'what is the text about' and to signal what the speaker think is important starting point. By having knowledge about the Theme of sentences, students can be able to comprehend long text as well as organize their writing.

Studies related to the implementation of genre-based approach have been conducted by researchers for years. The study conducted by Najmi (2015) in Iran revealed that the phases of teaching learning cycle in genre-based approach have created a great impact on participants. Based on the result, teachers in classroom are suggested to introduce many well- 
written sample reading text so that students can identify and realize the purpose, language features, and structure of particular text. It is in line with the study conducted by Lee (2012) in Hong Kong. The study highlighted the importance of teachers' role in making plan for the whole academic year. Teachers in the same school should exchange their views regarding specific genre they have to teach, develop teaching resources and feedback form, divide the works, and collaborate each other. The study also showed that factor facilitating the genre innovation in teaching are teachers' willingness to work collaboratively, teachers' professional knowledge and skill related to genre, and students' language abilities and learning motivation.

In Indonesian context, based on several studies, SFL GP can help learners in learning English, especially writing skill because all activities involved in SFL GP were complement each other and contributed in improving students' writing ability (Emilia \& Hamied, 2015). However, a study conducted by Nurviyani (2013) revealed that many junior high school teachers' understand genre-based approach superficially. The data obtained from the classroom observation also shows that the teachers applied the approach partially and the teacher employs the approach in certain skills only.

Although there are few things should be improved in implementing genre-based approach, it can be said that one of the main goals of genre-based approach is to help students become more successful writers and readers as well as to help them make sense of not only the structure of texts but also a wide range of compositional concerns (Brook, 2000 in Emilia, 2005). Therefore, this paper will focus on analyzing student's writing and how teachers can help students to solve students' problems in writing through the pedagogical plan.

Based on the aforementioned objectives, the concern of the study can be summarized in the following research questions:

1. What are common problems found in students' recount text?

2. What pedagogical plan is proposed related to the common problems found in students' recount text?

\section{RESEARCH METHODOLOGY}

Because error analysis is considered as a qualitative research, this study used a descriptive qualitative method. The subject in this study is the tenth grade students of a vocational school 
in Bandung, hotel accomodaction program. Using purposive sampling, one text was chosen as a sample out of 20 texts. Furthermore, recount text was chosen because it is one of the texts that had already learned by students in junior high school.

There are three main activities on analyzing the data quantitatively. They are data reduction, data display, and conclusion drawing or verification. After collecting the data, the study reduces the data by anticipatory (Miles \&Huberman, 1994). The data was gained through analyzing a student's recount text. The common errors in the student's writing were calculated and classified by using three metafunctions framework in SFL perspectives. After that, the data were all interpreted descriptively.

\section{RESULTS \& DISCUSSION}

\section{Student's Writing Analysis Based on The Three Metafunctions}

\section{a. Interpersonal Metafunction}

Interpersonal metafunction deals with establishing a relationship between people who are involved in communication. It can be recognized in the system of Mood and modality. The Mood analysis consists of mood type, Subject and Finite, and modality analysis.

There are four types of mood which is usually found out in the text: declarative, interrogative, imperative, and exclamative mood. Related to the type of mood, the student's writing use only declarative sentences to express his intention in telling his holiday experience. It indicates that the student attempts to deliver information to the readers about their experiences in form of recount text. It is corresponding to the general form of recount text which is usually written in declarative sentences.

Mood consists of two elements: Subject and Finite. Based on the 19 clauses in the student's writing text, it can be found out that the student mostly used pronoun 'I' as the subject. The other subject used in the text is the pronoun 'we' and it is used only in two clauses (clause 8 and 10). However, there are also four clauses in the text which have no subject as follows:

(4) I did a lot of activities such as playing playstation together with my cousins (5) and go to mall

(8) Me and my friends while a group photo (9) after finished playing game

(14) I do not know what to do (15) so take selfie

(18) because there's no activity (19) and only play my smartphone

The clauses in above sentences are connected with conjunctions. It can be concluded that the student is still confused in arranging a compound or complex sentences in terms of the 
subject. The clause number 8 also indicates that the students have not been able to use compound subject correctly.

Another constituent of mood analysis is the Finite. Finite can be a mark of time of the events happened. As aforementioned before, since recount text is intended to tell the past experience, the features of the text should be in the form of past tense. From 19 clauses, the student used the form of present tense in 9 clauses. The examples of the clauses using simple present tense are as follows:

(6) and before I go back to bandung

(10) we are devoted to recalls memories photo

(11) when I'm photographed with my friends

(14) I do not know what to do

(17) I'm take selfie

The clauses above indicate not only that the student faces difficulties in using past tense consistently but also he encounters problems in using passive voice as shown by clauses number 10 and 11 . The meaning of the clause cannot fully comprehend because the clauses may be directly translated from the student's first language.

In addition, one clause of the text can be categorized as non-finite clause since it does not use finite to mark its tenses.

(7) I doing things together with my old friends.

Thus, because of the missing Finite, the above clause is ungrammatical.

Modality is also an element analyzed in interpersonal metafunction. However, the use of modality cannot be found in the student's writing.

\section{b. Experiential Metafunction}

The analysis of experiential or ideational metafunction deals with the function of language used in communication to express experience and ideas to represent what is going in in the world. Transitivity analysis, which consists of three components: participant, process, and circumstance, is used to figure out experiential meaning in the text.

There are six main processes that can be found in Transitivity analysis: material, relational, mental, verbal, existential, and behavioral processes. However, one main characteristic of a recount text is the use of material process. The material process states 
about actions that are done by the participant. Thus, the clause with a material process have a doing (process) and a doer (participant) (Gerot and Wignel, 1995).

Material process is the main process can be identified in the student's writing text. There are 16 clauses of 19 clauses in the text use material process. Through material process used in the text, the student tried to inform readers about the activities or what he did in the events. The examples of material process found in the text are:

(1) My last vacation, I went to bekasi to visit my aunt and my uncle and my cousin

(3) When I arrived there

Material processes can be identified in the clause are went and arrived. From the example, the readers will know what kind of activities did by the writer during his holiday experience.

There are also three others processes found in the text. They are:

(14) I do not know what to do

(16) I'm in my own room

(18) because there's no activity

The verb used in clause number 14 (know) represents the mental process. The mental process deals with the inner world of cognition, perception, inclination, or liking/disliking (Butt, et.al. 2006). While the clause number 16 shows the relational attributive process which is expressed by be (I'm), the clause number 18 represent the use of existential process. The process exists between relational and material process and it shows the existence of something.

In the Transitivity analysis, beside analyzing the process represented by the verb in the clauses, the kind of participants involved in the text can also be analyzed. There are many kinds of participants related to experiential metafunction. However, since there are only four kinds of processes found in the text, the participants involved will also related to those processes. The example of the participants found in the text is as follows:

\begin{tabular}{|l|c|c|c|c|}
\hline & when & I & Arrived & there \\
\hline Experiential & & Actor & $\begin{array}{l}\text { Process: } \\
\text { Material }\end{array}$ & Circumstance \\
& & & \\
\hline
\end{tabular}

\begin{tabular}{|c|c|c|c|c|}
\hline & I & do not & know & what to do \\
\hline Experiential & Senser & \multicolumn{2}{|c|}{ Process: Mental } & Phenomenon \\
\hline
\end{tabular}

\begin{tabular}{|l|l|l|l|}
\hline & I & 'm & in my own room \\
\hline
\end{tabular}




\begin{tabular}{|l|l|c|c|}
\hline Experiential & Carrier & $\begin{array}{c}\text { Process: } \\
\text { Attributive }\end{array}$ & Attribute \\
\hline
\end{tabular}

\begin{tabular}{|l|l|l|l|l|}
\hline & Because & There & 's & no activity \\
\hline Experiential & & & Existential & Existent \\
\hline
\end{tabular}

\section{c. Textual Metafunction}

Textual metafunction gives information about the writer's idea in a text. It can be analyzed by identifying repetition, conjunction, and thematization (Thompson, 2014). Thematization in the text can be achieved by using Theme and Rheme analysis. There are three different types of theme: topical, textual, and interpersonal theme. The findings of Theme in the student's recount text can be seen in the table below.

\begin{tabular}{|l|c|}
\hline Type of Theme & \\
\hline Unmarked Topical Theme & 9 clauses \\
\hline Marked Topical Theme & 2 clauses \\
\hline Textual Theme & 8 clauses \\
\hline Interpersonal Theme & - \\
\hline
\end{tabular}

The findings above show that the student frequently used unmarked topical theme. The examples of the themes found in the text are:

\begin{tabular}{|l|c|c|c|c|c|}
\hline & I & Did & $\begin{array}{c}\text { a lot of } \\
\text { activitie } \\
\text { s }\end{array}$ & $\begin{array}{c}\text { such as } \\
\text { playing } \\
\text { PlayStation }\end{array}$ & $\begin{array}{c}\text { together with } \\
\text { my cousins }\end{array}$ \\
\hline Textual & THEME: Unmarked Topical & & \multicolumn{3}{c|}{ RHEME } \\
\hline
\end{tabular}

\begin{tabular}{|c|c|c|c|c|c|c|}
\hline & My last vacation & I & went & $\begin{array}{c}\text { to } \\
\text { bekasi }\end{array}$ & $\begin{array}{c}\text { to } \\
\text { visit }\end{array}$ & $\begin{array}{c}\text { aunt and my } \\
\text { uncle and my } \\
\text { cousin }\end{array}$ \\
\hline Textual & $\begin{array}{c}\text { THEME: } \\
\text { Marked Topical }\end{array}$ & \multicolumn{3}{|c|}{ RHEME } \\
\hline
\end{tabular}




\begin{tabular}{|c|c|c|c|c|}
\hline & when & I & Arrived & there \\
\hline Textual & \multicolumn{2}{|c|}{ THEME: } & \multicolumn{2}{|c|}{ RHEME } \\
\hline
\end{tabular}

From the findings and the examples above, we can conclude that most of themes exist in the text are unmarked topical theme since the topical theme is the subject of the clauses. Marked topical theme is used to call a topical theme which is not the subject of the clauses. For example, in the text, we can find my last vacation and at that time. On the other hand, textual themes relate the clause to its context. The theme of the clauses can be conjunctive adjunct and conjunction (Gerot and Wignell, 1995).

In the text, $I$ is the predominant Themes. The student seems face difficulties in connecting one sentence to another sentence. Repetition or the use of synonym which function is to keep readers' focus on the main idea is rarely found in the text. In some aspect, it makes the sentences were written separately. Thus, it can be concluded that the theme progression of the text has not well-developed yet. Furthermore, it can be said that the text is still lack in coherence and cohesion.

\section{Analysis Based on the Structure of the Text, Mechanics of Writing, and Grammatical}

\section{Errors}

\section{a. Generic Structures of Recount Text}

As mentioned before, generally, a recount text consists of three parts: orientation, series of events, and re-orientation. Although it is said that re-orientation is optional, a personal recount text usually provides personal comment of the writer to close the text.

\section{Orientation}

(1) My last Vacation, I went to bekasi to visit my aunt and my uncle and my cousin

(2) I went to use the bus

\section{Events}

(3) When I arrived there,

(4) I did a lot of activities such as playing playstation together with my cousins

(5) and go to mall

(6) and before I go back to bandung

(7) I doing things together with my old friends. 
(8) Me and my friends while a group photo

(9) after finished playing the game

(10) We are devoted to recalls memories photo

(11) When I'm photographed with my friends

(12) at that time, I was playing at a friends house one.

(13) I was accompanying my younger brother working on the task.

(14) I do not know what to do

(15) so take selfie

(16) I'm in my own room,

(17) I'm take selfie

(18) because there's no activity

(19) and only play my smartphone

The table above shows the clauses in the text. The orientation part begins with the introduction of the participants, and the setting of the event. In the second part, the writer wrote several events happened during his holiday. Unfortunately, the events are not quite well-sequenced, especially transition of the events in clause 12 to clause 13 . In addition, the re-orientation stage as a closure if a text is also not provided by the writer.

\section{b. Mechanics of Writing}

The mechanics of writing is the term used to describe the technical aspect in writing such as spelling, punctuation, and capitalization. A well-written text usually has a good mechanics so it will ease readers in reading the text. In the recount text written by the student, there are some mistakes in terms of mechanics of writing. The first error can be found in capitalization and the second is in punctuation.

(1) My last Vacation, I went to bekasi to visit my aunt and my uncle and my cousin

(6) and before I go back to bandung

The clauses above show that the student did not use capital letter to write the name of a city such as Bekasi and Bandung. Moreover, he used capital letter to write vacation while the word which is in the middle of the sentence does not require the capital letter. 
The full stop (.) is important to sign the end of the sentences. However, in the text above, the student rarely used the full stop at the end of the sentences. In few parts, the writer also did not use the comma (,) to mark slight break between certain parts of the sentences.

\section{c. Grammatical Errors}

A well-written text with a good grammar will help the writer to deliver the meaning to the readers. It also helps readers to understand the text better. Several grammatical errors found in the text can make the reader confused in comprehending the text both as sentence and as a text in a whole. The grammatical errors found in the text cover the use of subject in few clauses, the use of preposition, and the use of tenses and passive voice in few sentences. The examples of grammatical errors in the text are:

- My last Vacation, I went to bekasi to visit my aunt and my uncle and my cousin

- I went to use the bus

- I doing things together with my old friends.

- Me and my friends while a group photo

- after finished playing the game

- We are devoted to recalls memories photo

- When I'm photographed with my friends

- at that time, I was playing at a friends house one.

- I'm take selfie

\section{Pedagogical Implication}

In general, to solve problems in students' writing, teachers should consider strategies and techniques that will improve students' writing skills. Based on the errors found in the sample of student's writing text, POWER strategy is one of a ways that can be adapted by teachers in teaching writing. POWER is a total set of strategies which stood for the five steps in writing process: plan, organize, write, edit, and revise (Englert et al., 1991). The POWER strategy consists of three stages. The first stage is a prewriting stages which includes planning and organizing. The second stage is writing and it includes write step as a core activity in writing instructions. The last stage is the post-writing stage which includes editing and revising (Sari, Rifqoh, \& Febriana, 2017).

In the planning step, students should be able to synthesize information from various sources. In this initial stage of writing, teachers can utilize activities such as brainstorming or 
listing ideas. In this step, teachers should also ask their students to focus on the audience of their writings, the purpose of the text, and the background knowledge needed to write the text.

Organizing step requires students to be able to arrange ideas. Using organizing think sheet, teachers can ask their students to complete a pattern guide so students will organize their writing better.

In writing step, students should be able to use material prepared in pre-writing stage to produce a first draft. In this step, students should focus not only on grammar and mechanics, but also on ideas in their writing.

In editing, teachers help students to identify areas in which they need help. Students should check writing conventions and proof read their paper. The process of editing can be done in two ways: self-evaluation and peer editing.

The last step in POWER strategy is revising. In revising step, students make changes based in their self-evaluation sheets and peer feedback. Students should revisiting and reseeing their writing to verify whether or not their writing has clear purposes and well developed. Thus, this step involves activities such as adding, deleting, and changing content.

In general, the POWER strategy is aimed to improve students' writing skills in organizing ideas, developing information and ideas, editing, and revising. This strategy can be applied in all writing tasks including essays, short stories, and research papers.

Based on SFL perspective, related to errors found in students' writing, the steps in POWER strategy can give benefits for both students and teachers. For example, the use of planning sheets can help students to focus on social purpose they want to achieve through their writing. By using organize think sheet, problems in determining structure of the text can be solved. By organizing their ideas, students can be able to identify generic structure of particular text they will write. Last, in writing step, teachers should emphasize the use of what and who, how, where, when, and why. Those questions can ease students to focus on what they are going to write and can solve students' problem in interpersonal and textual metafunction.

Furthermore, the use of POWER strategy is also beneficial since it can promote discovery, collaborative, and students-centered learning. 


\section{CONCLUSION}

Writing is a productive skill that required students' ability to generate and organize ides using appropriate vocabularies. However, most students could not produce their own writing because they have not exposed to good resources of reading and in many cases, they face difficulties to comprehend texts. Learning English through genre is expected to be one of ways to improve students' comprehension in English, especially in their reading and writing skills.

After analyzing the text in several aspects, it can be identified that the student may encounter problems in composing a text. Although recount text is quite easy for a high school student, the student should have enough knowledge in choosing words, in using appropriate tenses related to the context of the events happened, and the use of conjunction to ensure that the text will be coherent. Therefore, in teaching and learning process, teachers will play important role in providing good sources of texts for students, guiding them to deconstruct the texts, and teaching them how to compose their own writing not only to share information but also to achieve the purpose of particular texts in the appropriate context and situation. One of the strategies can be used by teachers is the POWER strategy.

Considering that the three metafunction of Systemic Functional Linguistic is important in helping student to compose a text, the findings in this paper can be used for teachers to teach their students to produce the well-written text that is not only used to share information but also to clearly convey meaning and idea beyond the information itself.

\section{ACKNOWLEDGEMENTS}

I would like to express my great appreciation for contributors in this study. Special thanks should be given to LPDP for being a sponsor for my master study. This research was also supported by LPDP (Indonesia Endowment Fund for Education).

\section{REFERENCES}

Butt, D., Fahey, R., Feez, S., Spinks, S., \& Yallop, C. (2006). Using Functional Grammar: An Explorer's Guide (2nd Edition). Sydney: Macquarie University.

Derewianka, B. (1990). Exploring how texts work. Newtown: Primary English Teaching Association.

Derewianka, B. (2003). Trends and Issues in Genre-Based Approach. RELC Journal, 34(2), 133-154. https://doi.org/10.1177/003368820303400202 
Derewianka, B. (2015). The Contribution of Genre Theory to Literacy Education in Australia. In J. Turbill, G. Barton, \& C. Brock (Eds.), Teaching Writing in Today's Classroom: Looking back to looking forward. (pp. 69-86). Norwood, Australia: Australian Literary Educators' Association.

Dirgeyasa, I. W. (2016). Genre-Based Approach: What and How to Teach and to Learn

Writing. English Language Teaching, 9(9), 45-51. https://doi.org/10.5539/elt.v9n9p45

Emilia, E. (2005). A Critical Genre-Based Approach to Teaching Academic Writing in a Tertiary EFL Context in Indonesia. The University of Melbourne.

Emilia, E., \& Hamied, F. A. (2015). Systemic Functional Linguistic Genre Pedagogy (SFL GP) in A Tertiaty EFL Writing Context in Indonesia. TEFLIN Journal, 26(2), 155-182.

Englert, C. S., Raphael, T. E., Anderson, L. M., Anthony, H. M., Stevens, D. D., Englert, C.

S., ... Stevens, D. D. (1991). Making Strategies and Self-Talk Visible: Writing

Instruction in Regular and Special Education Classrooms. American Educational

Research Journal, 28(2), 337-372. https://doi.org/10.3102/00028312028002337

Gerot, L., \& Wignell, P. (1995). Making Sense of Functional Grammar: An Introductory Workbook. Australia: Gerd Stabler.

Hyland, K. (2007). Genre Pedagogy : Language , literacy and L2 writing instruction. Journal of Second Language Writing, 16, 148-164. https://doi.org/10.1016/j.jslw.2007.07.005

Knapp, P., \& Watkins, M. (2005). Genre, text, Grammar: Technologies for Teaching and Assessing Writing. New South Wales: University of New South Wales Press Ltd.

Lee, I. (2012). Genre-based Teaching and Assessment in Secondary English Classrooms. English Teaching: Practice and Critique, 11(4), 120-136.

Miles, M. B. \& Huberman, A. M. (1994). Qualitative Data Analysis (2nd edition). California: SAGE Publications, Inc.

Najmi, K. (2015). The Effect of Genre-Based Approach on Enhancing Writing Skill of Iranian Law Students. Modern Journal of Language Teaching Methods, 5(2), 474-484.

Nurviyani, V. (2013). The English Teachers' Understanding of Genre Based Approach. JOEPALLT, I, 1-13.

Sari, A. T. A., Rifqoh, A., \& Febriana, I. (2017). Using POWER Technique to Teach Writing Comprehension of Recount Text in Senior High School. Retrieved from https://www.academia.edu/6355656/Using_P-O-W-E- 
R_Technique_to_Teach_Writing_Comprehension_of_Recount_Text_in_Senior_High_S chool

Thompson, G. (2014). Introducing Functional Grammar (3rd Edition). New York: Routledge. 